\title{
THE GRAAFIAN FOLLICLE OF THE SHEEP : RELATIONSHIPS BETWEEN GONADOTROPHINS, STEROID PRODUCTION, MORPHOLOGY AND OOCYTE MATURATION
}

\author{
Mary F. HAY and R. M. MOOR \\ Agricultural Research Council, \\ Unit of Reproductive Physiology and Biochemistry, \\ 307 Huntingdon Road, Cambridge (England)
}

\section{SUMMARY} culture.

I. The Graafian follicle of sheep has been studied experimentally both in vivo and in organ

2. In vivo only one or two follicles possess the capacity to secrete significant amounts of œstrogen during the œstrous cycle. However, about $20 \mathrm{p}$. 100 of the non-active follicles were shown to be capable of secreting œstrogen in culture after they had been explanted from sheep that had been injected with PMSG 5 minutes previously.

3. Estrogen secretion by active follicles was arrested both in vivo and in vitro by an amount of luteinizing hormone corresponding with that released at ostrus.

4. In organ culture, the morphological integrity and steroidogenic capacity of the follicle was well preserved and $85 \mathrm{p}$. Ioo of the oocytes resumed meiosis, but many of the meiotic figures were abnormal. In the cultured follicles $(a)$ degeneration of the oocyte did not necessarily lead to luteinization of the granulosa cells, and $(b)$ luteinization sometimes occurred in the presence of a vesicular oocyte.

\section{INTRODUCTION}

Although it is generally accepted that follicular development is under the control of gonadotrophins, recent studies have suggested that the different cell types within the follicle may have a regulatory effect on each other (FooTE and ThibaulT, I969; NalBandov, 1972).

We have recently been studying various factors that regulate the production of steroids by the ovarian follicle as well as the maturation of the oocyte in sheep. Some of our findings are summarized and discussed in this paper. 


\section{I. - EXPERIMENTAL MODELS}

Two experimental models have been used, one for in vitro, and the other for in vivo studies.

For the in vitro studies, isolated sheep follicles were maintained in organ culture; details of the methods used have already been described (Moor, I973; Moor et al., 1973). The morphological integrity and steroid-secreting capacity of the follicles were well preserved in culture for 7-I4 days. The cultures were used to study the effect of hormones on the morphology and steroidogenic capacity of individual follicles; the maturation of the oocyte and its regulatory role within the follicle have also been examined under these controlled conditions.

For the in vivo experiments described in sections 3 and 4 , it was desirable to have animals in which the endocrine changes leading to ovulation could be predicted with some degree of accuracy. It was found that when the corpus luteum was removed on the 5 th day of the cycle, the ensuing hormonal changes showed a consistent pattern. Progesterone levels fell rapidly and remained low. Oestrogen levels rose between 16 and 24 hours after removal of the corpus luteum, remained high for a further 12-I6 hours, and then fell to reach base-line levels at 48 hours. LH levels were low in all sheep up to 32 hours after corpus luteum removal. During the following I 2 hours, LH levels rose to a peak lasting 6-Io hours. Ovulation occurred about 24 hours after the LH peak.

\section{II. - STEROID SECRETION BY OVARIAN FOLLICLES}

A detailed study of the contribution made by follicles of different sizes to the total output of œstrogen from the ovary at selected stages of the œstrous cycle has been made (Moor, 1973). In that study all the follicles measuring over $2 \mathrm{~mm}$ in diameter were explanted separately and the daily secretion of œstrogen by each follicle was measured. It was found that only the largest one or two follicles from each sheep secreted significant amounts of ostrogen into the culture medium. When the large follicles were explanted during the first four days of the cycle, œestrogen secretion in culture declined rapidly; this is probably a reflection of the atresia that occurs in such follicles at this stage (BRAND, I970). However, when the large follicles were explanted between the $4^{\text {th }}$ and the I 2 th days of the cycle, they secreted œstrogen at relatively high and constant levels (about $300 \mathrm{ng} /$ day) throughout the whole 7 -day culture period. The pattern of cestrogen secretion of large follicles explanted during the last three days of the cycle varied, and was characteristic for the day of explantation. This is illustrated in figure $I$, in which is also shown the mean oestrogen production of all small follicles in culture. The small follicles secreted consistently low levels of œstrogen regardless of the stage of the cycle at which they were explanted.

Of particular interest is the sequence of steroid changes that occurs immediately before maturation of the oocyte. This sequence was studied by analyzing, in more detail, the medium in which large follicles explanted around œstrus had been cultured (R. F. SEAmark, R. M. Moor et J. E. A. McINTOSh, unpublished). As oestrogen levels dropped, there was a sharp but transitory rise in testosterone and I7-hydroxy- $\Delta^{5}$-pregnenolone, followed by a rapid and large increase in the production of progesterone and 20 $\alpha$-dihydroprogesterone. The role of these steroids in the process of luteinisation and oocyte maturation is being studied. 
A histochemical study has been made of the distribution and cellular localization of the enzyme $\Delta^{5}-3 \beta$-hydroxysteroid dehydrogenase (HSD) which plays a key role in steroid biosynthesis. Its presence in the ovarian follicles at various stages of the œstrous cycle has been related to the levels of œestrogen in the venous effluent from the appropriate ovary. By this method it has been possible to identify those follicles which possess the potential for secreting cestrogen. From the results, it became clear that only one or two of the large follicles in each sheep exhibit HSD activity, and that this activity is confined to the theca interna. From the 15 th day of the cycle up to the time of ovulation the follicle that exhibits HSD activity is the largest one and is invariably found in the ovary whose venous blood has the highest œstrogen concentration. These findings support the conclusions drawn from the culture experiments that only one or two follicles in each sheep secrete significant levels of œstrogen.

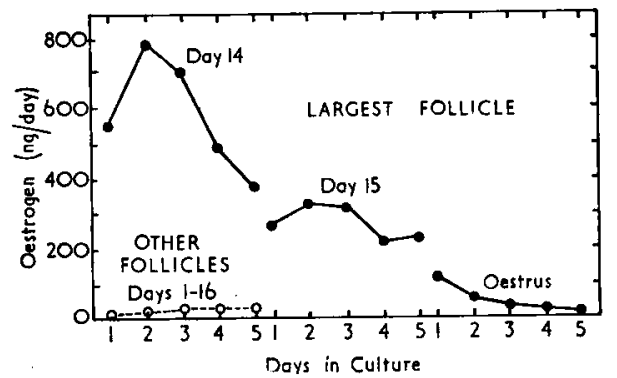

FiG. I. - Mean daily production of cestrogen by the largest follicles explanted from untreated sheep on the 14th and 15th days of the cycle and at cestrus. Also shown is the mean daily output of cestrogen from all other follicles explanted from untreated sheep throughout the cycle.

FIG. I. - Production journalière moyenne d'cestrogènes: par les plus gros follicules prélevés sur des Brebis non traitées le 14 et $15 \mathrm{e}$ jour du cycle et à l'aestrus, par tous les autres follicules prélevés sur des Brebis non traitées tout au long du cycle.

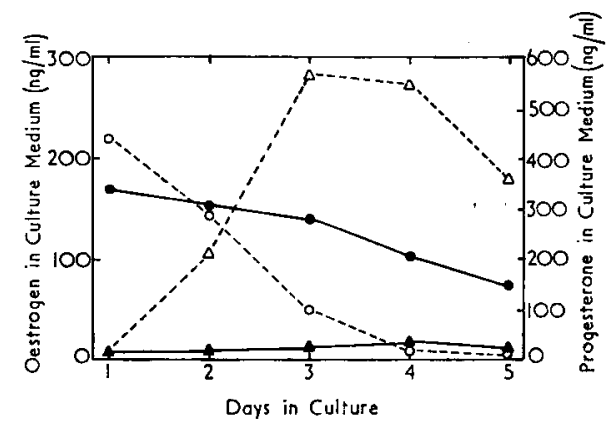

FIG. 2. - The effect of $L H$ on the production of steroids by active follicles explanted from sheep 24 hours after PMSG injection. LH $(5 \mu \mathrm{g} / \mathrm{ml})$ was added to the treated group of follicles 24 hours after explantation.

Estrogen $(\bullet-\bullet)$ and progesterone $(\Delta-\Delta)$ production curves for control follicles Estrogen $(0-\cdots)$ and progesterone $(\Delta-\cdots-\Delta)$ production curves for LH-treated follicles

FIG. 2. - Effet de LH sur la production de stéroïdes par des follicules actifs prélevés 24 heures après injection de PMSG. LH $(5 \mu \mathrm{g} / \mathrm{ml})$ est ajoutée au groupe de follicules traités 24 heures après la mise en culture.

\begin{tabular}{|c|c|}
\hline Follicules témoins & —_ ostrogenes \\
\hline
\end{tabular}




\section{III. - EFFECTS OF GONADOTROPHINS ON OESTROGEN SECRETION BY THE FOLLICLE}

It has been pointed out that apart from the largest follicle none of the other follicles in the ovary is capable of secreting significant amounts of cestrogen in vivo or in vitro. In this section, the ability of small follicles to secrete œstrogen under the influence of a single injection of pregnant mare serum gonadotrophin (PMSG) will be discussed. The gonadotrophin was injected during the luteal phase of the cycle (between days 4 and I2) when the output of cstrogen by the ovaries was low. Within I2-24 hours of the injection, the concentration of cestrogen in the ovarian venous blood rose markedly, and a number of small follicles increased in size and acquired HSD activity.

By explanting follicles at selected times after the injection of PMSG it was possible to determine the interval of time during which a follicle had to be exposed to the influence of PMSG in vivo in order to become capable of secreting estrogen. It was found that even after an exposure period as short as 5 minutes, about $20 \mathrm{p}$. Ioo of the small follicles became active and subsequently secreted significant amounts of œstrogen in culture. Neither the percentage of follicles stimulated nor the amount of œestrogen produced by each follicle was increased by extending the interval between PMSG injection and explantation of the follicle from 5 minutes to 12 hours. Since it is already known that only about 20 p. Ioo of the follicles measuring more than $2 \mathrm{~mm}$ in diameter show no signs of atresia in normal cyclic sheep (BRAND, r970), it seems likely that the $20 \mathrm{p}$. Ioo of follicles activated by exposure to PMSG for times up to I 2 hours must have been derived from the non-atretic population. When the interval between PMSG injection and explantation was extended to 24 hours about 80 p. Ioo of the follicles became active in vitro: the mean daily production of ostrogen by these follicles was about three times that of follicles exposed to PMSG for I2 hours or less.

In addition to the experiments in which PMSG was injected parenterally, an attempt has been made to determine the effect of various gonadotrophins administered to small follicles directly. No stimulation of oestrogen secretion was obtained by the microinjection in vivo of either 5 i.u. PMSG, or 20-50 $\mu$ g FSH (NIH-FSH-S9) into the lumen of the follicle. Infusion of 50-I0o i.u. PMSG into the ovarian artery, however, stimulated the small follicles to the same degree as I ooo i.u. PMSG administered systemically. Several attempts have also been made to stimulate small follicles in vitro by adding PMSG, FSH, prolactin or LH alone or in combination to the culture medium. However, none of the treatments has stimulated small follicles to secrete significant amounts of cestrogen.

Since a number of hormones including gonadotrophins are found in follicular fluid, it was of interest to determine whether this reservoir of hormones exerts a direct action on the steroidogenic capacity of follicles. Follicular fluid was therefore removed from a number of active follicles before they were placed in culture. The daily output of œstrogen and progesterone from these follicles over the 7-day culture qeriod was not significantly different from that of intact controls. Thus, steroid pro- 
duction in culture does not appear to be significantly influenced by the gonadotrophins in the follicular fluid.

In normal cyclic sheep, cstrogen secretion from the ovary with the largest follicles rises from low levels on day $\mathrm{I}_{3}$ of the cycle to a peak on day $\mathrm{I}_{5}$ and then declines sharply to base-line levels at œstrus. The mechanism that controls this decline is unknown, but a temporal relationship exists between the decline in ostrogen production and the pre-ovulatory rise in $\mathrm{LH}$ secretion. Experiments have been carried out to determine whether these two hormonal events are causally related.

In order to study the effect of high circulating levels of $\mathrm{LH}$ on the secretion of cestrogen, a total of I mg LH (NIH-L $\mathrm{LH}_{-} \mathrm{SI}_{7}$ ) was infused over 6 hours into the jugular vein of sheep from which the corpus luteum had been removed 18 hours previously. The amount of $\mathrm{LH}$ infused and the duration of the infusion corresponded with the release of $\mathrm{LH}$ that occurs naturally in sheep at cestrus. The infusion of $\mathrm{LH}$ prevented the ovary from secreting the large amounts of œstrogen it would otherwise have done 24-40 hours after removal of the corpus luteum (see section I).

The action of $\mathrm{LH}$ on ostrogen production was investigated further by adding LH in vitro to follicles taken from sheep treated with PMSG 24 hours previously. The addition of $\mathrm{L}_{\mathrm{H}} \mathrm{H}$ to the culture medium (5 $\left.\mu \mathrm{g} \mathrm{NIH}-\mathrm{L} / \mathrm{H} / \mathrm{ml}\right), 24$ hours after explantation of the follicles, caused a sharp drop in ostrogen production, a transitory rise in testosterone and $I_{7}$-hydroxy- $\Delta^{5}$-pregnenolone and then a marked rise in progesterone secretion; this sequence of hormonal changes is similar to the one observed in follicles explanted at cestrus (see section 2). On the other hand, when œstrogen-secreting follicles were cultured in the absence of $\mathrm{LH}$ (control medium), œstrogen output declined only very slowly and there was no significant production of progesterone during the 5-day culture period (fig. 2).

The effect of LH on the steroidogenic capacity of the cultured follicles was reflected in their morphology and histochemistry. Within two days of the addition of LH to the culture medium, the granulosa cells underwent luteinization, they showed HSD activity, and the output of progesterone was high. In the control cultures, on the other hand, HSD activity in the granulosa cells was not observed before the fifth day and there was very little luteinization.

From the results obtained in vivo and in vitro it can be concluded that at high levels $\mathrm{LH}$ acts directly on the follicles in such a way as to inhibit œestrogen secretion and at the same time to stimulate luteinization of the granulosa cells and the secretion of progesterone.

\section{IV. - INTRAFOL,ICULAR REI,ATIONSHIPS}

\section{Maturation of the oocyte in vivo and in vitro}

In the normal sheep the nucleus of the oocyte in the preovulatory follicle was found in the vesicular stage until 8-I2 hours after the onset of ostrus, at which time it entered metaphase I. The metaphase II configuration was generally seen I 8-24 hours after the onset of cestrus.

In sheep in which the corpus luteum had been removed and LH subsequently 
infused (see section $I$ ), the oocytes in the preovulatory follicles resumed meiosis within 8 hours of the end of the infusion, and I6 hours later were found in metaphase II.

About $85 \mathrm{p}$. Ioo of follicles over $2 \mathrm{~mm}$ in diameter cultured under our conditions showed maturation changes within 24 hours. The majority of these changes, however, were abnormal; the most common abnormalities were retention of the nuclear membrane in metaphase $\mathrm{I}$, abnormal arrangement of the chromosomes and excessive vacuolisation of the cytoplasm (see plate I). The other I5 p. Ioo of cultured follicles remained in the vesicular stage for up to 5 days. It is possible that the large number of abnormal oocytes was due to the high oxygen concentration ( $45 \mathrm{p}$. IOo) which was necessary to maintain good structural and functional integrity of the theca and granulosa cells.

\section{Interactions between the oocyte and the granulosa cells}

The results of our experiments designed to study the cellular relationships within the follicle are equivocal because of the high percentage of oocytes that underwent abnormal changes in culture. Some of our results are of interest, however, when compared with the findings of other workers. It has for example been shown by Foote and THIBAULT (I969) that the resumption of meiosis in bovine oocytes is inhibited by the presence of viable corona and granulosa cells. Under our culture conditions maturation changes in sheep oocytes frequently occurred within 24 hours of explantation despite the maintenance of a normal topographical relationship between healthy granulosa, cumulus and corona cells (P1. I, fig. I and 2); however, it is possible that maturation changes of an entirely normal nature might have been prevented by the presence of viable cumulus and granulosa cells. The reciprocal relationship, namely that the oocyte exerts an inhibitory influence on the process of granulosa cell luteinisation has been postulated by NALBANDOW and his co-workers (see NALBANDOv, 1972). It would appear from our results, however, that I) degeneration of the oocyte does not of itself necessarily lead to luteinization of the granulosa cells and the production of progesterone. In the follicles that contained degenerate oocytes, œstrogen production was often high and the output of progesterone negligible (as in fig. 2) ; the granulosa cells retained their morphological characteristics and showed no sign of luteinization (P1. I, fig. 3 and 4). (2) Luteinization and progesterone secretion occur in vitro in LH-treated follicles in the presence of apparently normal oocytes in the vesicular stage. Plate $I$, figure 6 shows such an oocyte on day 5 ; the granulosa cells were clearly luteinized in this follicle which had been producing high levels of progesterone since the second day in culture (pl. I, fig. 5).

\section{ACKNOWLEDGEMENTS}

We wish to acknowledge with appreciation the skilled technical assistance of Mr D. GREEN and Mrs H. K. Levinson. We are grateful to Dr C. E. Adams, Dr H. M. Dot and Professor T. R. R. MANN for reading and discussing the manuscript. Our thanks are due to the Endocrinology Study Section, National Institutes of Health, for the generous gift of LH, FSH and prolactin. 


\section{RÉSUMÉ}

\section{LE FOLLICULE DE GRAAF DE LA BREBIS : RELATIONS ENTRE LES GONADOTROPINES, IA PRODUCTION DE STÉROÏDES, LA MORPHOLOGIE DU FOLLICULE ET LA MATURATION DE L'OVOCYTE} gane.

Le follicule de Graaf de la Brebis a été étudié expérimentalement in vivo et en culture d'or-

In vivo, au cours d'un cycle ostrien, un ou deux follicules seulement sont capables de sécréter des quantités notables d'œestrogènes. Mais en culture, environ 20 p. Ioo des follicules inactifs sont capables de sécréter des œestrogènes quand on les prélève sur des Brebis ayant reçu, même seulement 5 minutes avant l'abattage, une injection de PMSG.

Aussi bien in vivo qu'in vitro, une quantité de LH correspondant à celle qui est libérée à l'œestrus, arrête la sécrétion d'œestrogènes par les follicules actifs.

En culture d'organe, la morphologie et l'activité stérö̈dogène des follicules sont bien préservées et 85 p. Ioo des ovocytes achèvent leur méiose, mais la plupart des images de méiose sont anormales. Dans les follicules cultivés, d'une part, la dégénérescence de l'ovocyte n'est pas nécessairement accompagnée de la lutéinisation des cellules de la granulosa, et d'autre part, la lutéinisation se produit parfois en présence d'un ovocyte présentant encore une vésicule germinative.

\section{REFERENCES}

BRAND A., 1970. Some micromorphological and biochemical aspects of the Texel sheep during the oestrous season. Thesis, University of Utrecht.

Foote W. D., Thibault C., rg69. Recherches expérimentales sur la maturation in vitro des ovocytes de truie et de veau. Ann. Biol. anim. Bioch. Biophys., 8, 329-349.

Moor R. M., I973. Oestrogen production by individual follicles explanted from ovaries of sheep. $J$. Reprod. Fert., 32, 545-548.

Moor R. M., Hay M. F., McIntosh J. E. A., CALDwell B. V., I973. Effect of gonadotrophins on the production of steroids by sheep ovarian follicles cultivated in vitro. $J$. Endocr. (In press).

Nalbandov A. V., 1972. Interaction between oocytes and follicular cells. In Oogenesis, p. 513-522. Eds J. D. Biggers and A. W. Schuetz, Baltimore : University Park Press and London : Butterworths. 


\section{PLATE I}

Three follicles explanted on day 14 of the cycle, 24 hours after the sheep had been injected with PMSG, showing the follicle wall and associated oocyte

FIG. I and 2. - Cultured 24 hours in control medium. The oocyte shows metaphase II configuration but the nuclear membrane is still present. The surrounding corona and cumulus cells are normal and there is no luteinization of the granulosa cells. (Fig. I $\times$ I00; fig. $2 \times 480$.)

FIG. 3 and 4. - Cultured 4 days in control medium. The granulosa cells have not luteinized despite the presence of a degenerate oocyte. (Fig. $3 \times 400$; fig. $4 \times 480$.)

FIG. 5 and 6 . - Cultured 5 days in medium containing $5 \mu \mathrm{g}$ $\mathrm{LH} / \mathrm{ml}$. Luteinization of the granulosa cells has occurred without maturation of the oocyte which is still in the vesicular stage. (Fig. $5 \times 400$; fig. $6 \times 400$.)

\section{PLANCHE I}

Trois follicules prélevés le $14^{\mathrm{e}}$ jour du cycle 24 heures après injection de PMSG à la Brebis: paroi du follicule et ovocyte associé

FIG. I et 2. - 24 heures de culture dans le milieu témoin. L'ovocyte est en métaphase II, mais la membrane nucléaire est encore présente. Les cellules de la corona et du cumulus sont normales et on n'observe aucune lutéinisation des cellules de la granulosa.

FIG. 3 et 4 . -4 jours de culture dans le milieu témoin. Les cellules de la granulosa ne sont pas lutéinisées, malgré la présence d'un ovocyte dégénéré.

FIG. 5 et 6 . - 5 jours de culture dans un milieu contenant $5 \mu \mathrm{g} \mathrm{LH} / \mathrm{m} 1$. La lutéinisation des cellules de la granulosa s'est produite sans maturation de l'ovocyte qui est toujours au stade de la vésicule germinative. 
PLATE I
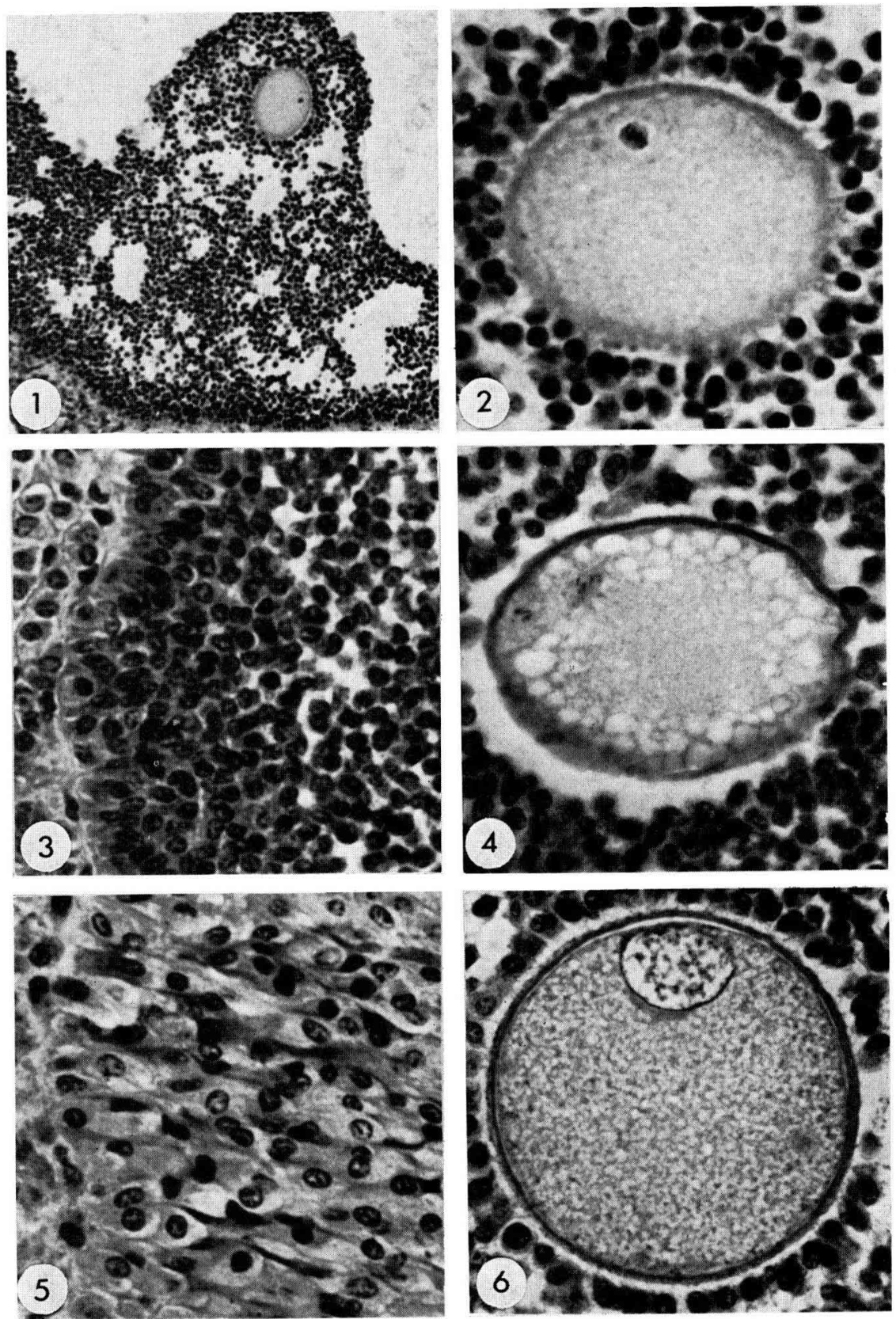

M. F. HAY and R. M. MOOR 